\title{
Evaluation of Synthetic and Natural Insecticides for the Management of Insect Pest Control of Eggplant (Solanum melongena L.) and Pesticide Residue Dissipation Pattern
}

\author{
Jayakrishnan Saimandir ${ }^{1}$, Madhuban Gopal ${ }^{2 *}$ \\ ${ }^{1}$ Department of Entomology, Ohio State University, Columbus, USA; ${ }^{2}$ Madhuban Gopal, Division of Agricultural Chemicals, Indian \\ Agricultural Research Institute, Pusa Campus, New Delhi, India. \\ Email: ${ }^{*}$ madhubangopal@gmail.com
}

Received November $20^{\text {th }}, 2011$; revised December $15^{\text {th }}, 2011$; accepted December $27^{\text {th }}, 2011$

\begin{abstract}
Eggplant shoot and fruit borer (ESFB), Leucinodes orbonalis G. is a key pest of eggplant, Solanum melongena L. Organophosphates (OP) having high toxicity and persistence are used to control the pests in many developing countries, despite availability of new insecticides with better qualities. Field evaluation of thiacloprid and indoxacarb were carried out against ESFB, with an OP insecticide, methyl parathion. Two Bacillus thuriegensis (Bt) based formulations namely Biolep and PUSA Bt and two azadirachtin formulations namely Neem Seed Kernal Extract (NSKE) and Nimbo Bas were also evaluated against ESFB for the management of the pest. HPLC and GC methods for the estimation of indoxacarb, thiacloprid and methyl parathion from the fruits were developed and their dissipation patterns and safety parameters were compared. For indoxacarb, the method involving Florisil gave highest recovery $(88 \%)$ whereas average recoveries of other methods varied from $59 \%$ to $82 \%$. The mean initial deposits of indoxacarb on fruits were 2.60 $\mathrm{mg} / \mathrm{kg}$ to $3.64 \mathrm{mg} / \mathrm{kg}$ and $2.63 \mathrm{mg} / \mathrm{kg}$ to $3.68 \mathrm{mg} / \mathrm{kg}$ from 75 and $150 \mathrm{~g} \cdot \mathrm{ai} / \mathrm{ha}$ treatments from two-year field studies. The half-life of indoxacarb was $3.0 \mathrm{~d}-3.8 \mathrm{~d}$ from both years. The Theoretical Maximum Daily Intake (TMDI) was found to be $0.446 \mathrm{mg} / \mathrm{person} /$ day to $0.643 \mathrm{mg} /$ person/day for day-1 residues which is in par with the Maximum Permissible Intake (MPI) of $0.6 \mathrm{mg} /$ person/day. The TMDI from $3 \mathrm{~d}$ residues was found to be less than the MPI calculated with the data of $3 \mathrm{~d}$ residues which ensures better margin of safety. For thiacloprid, the method involving Florisil gave highest recovery (89\%). The mean initial deposits of thiacloprid on fruits were 3.39 to $5.40 \mathrm{mg} / \mathrm{kg}$ and 3.40 to $5.39 \mathrm{mg} / \mathrm{kg}$ from 30 and $60 \mathrm{~g} \cdot \mathrm{ai} / \mathrm{ha}$ treatments from both years. The half-life values were determined to be 11.1 and $11.6 \mathrm{~d}$ for both years. The TMDI from maximum residues observed for first day for both the treatments during first year trials was found to be 0.682 to $1.098 \mathrm{mg}$ person/day, which was higher than the MPI of $0.72 \mathrm{mg} / \mathrm{person} / \mathrm{day}$, which proved that the application is toxic to humans. Thiacloprid at the experimented doses (30 and $60 \mathrm{~g} \cdot \mathrm{ai} / \mathrm{ha}$ ) was found not effective to manage ESFB and was not safe for human consumption after a waiting period of 3 days. For methyl parathion, the method involving Florisil gave highest average recovery ( $89 \%)$. The initial residues on fruits from recommended dose declined from 3.60 to $3.12 \mathrm{mg} / \mathrm{kg}$ in one day and $0.27 \mathrm{mg} / \mathrm{kg}$ in twentyfive days from $100 \mathrm{~g} \cdot \mathrm{ai} / \mathrm{ha}$. Similar pattern was observed with higher dose also. The dissipation rate constants were 0.123 and 0.140 for 100 and $200 \mathrm{~g} \cdot a \mathrm{i} / \mathrm{ha}$ treatments, respectively. The half life values ranged from 6.0 to 7.4 days. Using dose (100 g·ai/ha), the residues reached safe level only after 20 days. A minimum gap of 20 days after the last application of the insecticide to the harvest is impractical for this crop. The efficacy of methyl parathion against ESFB was good at lower dose, but due to its toxic residue profile there is a high health risk. Biolep at both doses were not effective against ESFB, however PUSA Bt gave better control against ESFB at similar dose. NSKE was found effective against ESFB, however NimboBas found to be non-effective against ESFB.
\end{abstract}

Keywords: Thiacloprid; Indoxacarb; Methyl Parathion; Persistence; Integrated Pest Management; Dissipation

\section{Introduction}

Eggplant is one of the important vegetables in India which contributes $9 \%$ of total vegetables in India [1]. It is a good source of nutrients, minerals, antioxidants, vita-

"Corresponding author. mins, dietary fiber and body building factors and proteins $[2,3]$. The biggest threat to eggplant cultivation is the wide spread infestation of ESFB in India and it is difficult to control since the insect larvae harbor inside the plant tissue. The larval form causes maximum damage to the edible fruit [4]. The adult moth of ESFB lays eggs on the 
leaf and hatched larvae move into the fruits. It was hypothesized that contact insecticides can control and prevent hatched larvae getting entry into the fruits and shoots, whereas systemic insecticides can be effective in controlling early developmental stages of borer when it is inside the plant tissue. Therefore, there is a need to evaluate systemic as well as contact insecticide to control the pest. Thiacloprid (Bay YRC 2894) is used for foliar application with systemic properties and broad-spectrum efficacy against sucking and biting insects [5-11]. Thiacloprid selectively acts on the insect nervous system as an agonist of the nicotinic acetylcholine receptor (nAChR) [12]. Indoxacarb is a broad-spectrum, contact, low risk pesticide with low mammalian toxicity and a benign profile for avian and aquatic toxicity [13-18]. It affects insects from direct exposure to spray droplets and through ingestion of treated foliage or fruit. Once absorbed, it kills by binding to a site on the sodium channel and blocking the flow of sodium ions and results in impaired nerve function, feeding cessation, paralysis, and death. Once indoxacarb is absorbed or ingested, feeding cessation occurs almost immediately even though it may take several days for the insect to die [19]. Along with these two, a commonly used OP insecticide, methyl parathion was also evaluated and its efficacy and residue behavior were compared with that of thiacloprid and indoxacarb. Methyl parathion is effective for controlling chewing and sucking insects in a wide range of crops, including cereals, fruit, vines, vegetables, ornamentals, cotton and field crops [20]. These chemicals have not been reported for managing ESFB of eggplant and there is no previous published work available on the residue behavior and persistence of these insecticides on eggplant fruits, we decided to study this aspect based on previous observations made about of efficacy of these insecticides.

The insecticides were applied systematically with a 14 day interval. To minimize the use of pesticides and in order to maintain a balanced natural enemy population, alternative approaches like cultural control, mechanical control and botanical insecticides were also used. Botanical pesticides like NSKE, Nimbo Bas ${ }^{\mathrm{TM}}$ (azadirachtin based formulation) and two Bt based bio-insecticides, namely PUSA Bt and Biolep ${ }^{\mathrm{TM}}$ were evaluated. The results of the study may be incorporated in IPM package for eggplant and may be able to reduce the cost of cultivation by reducing the quantity of pesticides which would be beneficial for both farmers as well as consumers.

\section{Materials and Methods}

\subsection{HPLC Analyses}

A Lachrom High Pressure Liquid Chromatography (HPLC) instrument equipped with quaternary pump, UV detector connected with auto-injector and a computer (model Hitachi) was used for analysis. The stationary phase consisted of Lichrosphere RP-18 packed in a stainless steel column $(250 \mathrm{~mm} \times 5 \mathrm{~mm}$ i.d.). Chromatogram was recorded in a Windows' NT based program. Operational parameters of HPLC for indoxacarb were given below. Mobile phase - aetonitrile: water (9:1); flow rate- 0.5 $\mathrm{mL} \cdot \min ^{-1} ; \lambda_{\max }-213 \mathrm{~nm}$; injection volume- $-10 \mu \mathrm{L}$; column and solvent temperature-ambient. Operational parameters for thiacloprid were, Mobile phase-acetonitrile: water $\left(6: 4 \mathrm{vv}^{-1}\right)$; flow rate $-0.5 \mathrm{~mL} \min ^{-1} ; \lambda_{\max }-213 \mathrm{~nm}$; injection volume- $10 \mu \mathrm{L}$; column and solvent temperature-ambient.

\subsection{Gas Chromatographic Analyses}

A Hewlett Packard 5890, Series II gas chromatograph was used for the analysis equipped with HP-1, megabore column (methyl silicon gum, $10 \mathrm{~m} \times 0.53 \mathrm{~mm} ; 2.65 \mu \mathrm{m}$ film thickness) and ${ }^{63} \mathrm{Ni}$ ECD detector. Oven, injection and detection temperatures were $250^{\circ} \mathrm{C}, 250^{\circ} \mathrm{C}$ and $300^{\circ} \mathrm{C}$, respectively. Carrier gas (Nitrogen) flow was 30 $\mathrm{mL} \cdot \mathrm{min}^{-1}$.

\subsection{Insecticides, Chemicals and Supplies}

Thiacloprid, Calypso 240 SC, Bayer Crop Science India Limited, India; Indoxacarb, Avaunt 14.5 SC, E. I. DuPont India Limited, New Delhi, India; Methyl parathion, Metacid 50 EC, Bayer India Limited, India; Biolep ${ }^{\mathrm{TM}}$, commercially available $B$. thuriegensis var. Kurstaki, Strain Z-52, Serotype H-3a, 3b, water dispersible powder formulation, Biotech International Limited, New Delhi, India; PUSA Bt, a WDP formulation prepared by own methodology in our laboratory and Department of Entomology, IARI, New Delhi [21]; NSKE, water extract of Neem, Azadirachta indica, (Family Meliaceae) seed kernel powder at required concentration; Nimbo Bas $1500^{\mathrm{TM}}$, 0.15 EC, an Azadirachtin based formulation. All solvents and chemicals used were from Merck Limited, India. Adsorbents used in the experiments were obtained from Sigma Chemicals Inc., USA.

\subsection{Field Experiment}

The studies on the dissipation of synthetic insecticides namely, indoxacarb, thiacloprid and methyl parathion on eggplant were carried out through field experiments during two consecutive seasons in 2004 and 2005. Insecticides of biological origin namely Biolep, PUSA Bt, NSKE and Nimbo Bas ${ }^{\mathrm{TM}}$ were considered only for efficacy evaluation during the same period. Eggplant seedlings, variety Hybrid-9, were transplanted on raised beds (plot size $4.2 \times 3.75 \mathrm{~m}^{2}$ ) during 2004 and 2005 at the experimental farm of Indian Agricultural Research Insti- 
tute, New Delhi, India. The plant-to-plant and row-to-row spacing was 60 and $75 \mathrm{~cm}$ respectively, for both the years. Thiacloprid was applied at the rate of 30 and $60 \mathrm{~g}$ active ingredient per hectare $\left(\mathrm{ai} \cdot \mathrm{ha}^{-1}\right)$ for both seasons. Indoxacarb was applied at the rate of 75 and $150 \mathrm{~g} \cdot \mathrm{ai}^{\mathrm{h}} \mathrm{ha}^{-1}$. Methyl parathion was applied at the rate of 100 and 200 $\mathrm{g} \cdot \mathrm{ai} \cdot \mathrm{ha}^{-1}$. For all synthetic pesticides a $4 \times$ dose were applied for phytotoxicity study. Bio pesticides like Biolep ${ }^{\mathrm{TM}}$ and PUSA Bt were applied at two concentrations i.e., 1 and $2 \mathrm{~kg} \cdot \mathrm{ha}^{-1}$ for both the seasons. NSKE was applied at $5 \%$ and $10 \%$ for both the seasons. Nimbo Bas ${ }^{\mathrm{TM}}$ was applied at two concentrations i.e., 1 and $2 \mathrm{~L} \cdot \mathrm{ha}^{-1}$ for the two seasons. The insecticides were sprayed on the eggplant crop just after some fruits had set in. Fourteen days later, a second spray was given. The fluid rate was $500 \mathrm{~L} \cdot \mathrm{ha}^{-1}$ for both the sprays. All the treatments were in Randomized Block Design (RBD) and taken in three replicates including untreated control. Each insecticide was applied in separate eggplant plots and in each plot, four random plants were tagged and periodic observations were made to estimate percent fruit damage throughout the cropping season. The parameter observed was the hole made by ESFB larvae on the fruit. The observation included the damage in terms of number of fruits and weight of fruits.

\subsection{Field Sample Collection}

For determining dissipation of thiacloprid, indoxacarb and methyl parathion from the eggplant fruits and to assess dietary intake exposure and consumer risk, the a representative fruit samples $(500 \mathrm{~g})$ were collected on $0 \mathrm{~d}$ (1 $\mathrm{h}$ after insecticide application), 1, 3, 5, 7, 10, 15, 20 and $25 \mathrm{~d}$ from both the trials. The samples were stored in freezer and processed on the same day. The fruits were cut into small pieces, mixed and a sub sample of $50 \mathrm{~g}$ was taken for further analysis. Based on the results of the recovery experiments, the optimum conditions suited were adopted for the analysis of field samples as per the method of Jayakrishnan [22]. The efficiency of extraction, cleanup and determinative steps for synthetic insecticides were checked by recovery experiments after fortifying the eggplant fruits.

\subsection{Recovery Experiment for Indoxacarb}

Untreated eggplant fruits $(50 \mathrm{~g})$ were spiked separately with 5, 25 and $50 \mu \mathrm{g}$ of indoxacarb and kept for $24 \mathrm{~h}$. Fortified samples were homogenized, extracted with acetone, filtered, rotary evaporated and the extracts were subjected for partitioning with acetonitrile (10 mL, 3 times), so that the pesticide moved into it from aqueous remain. Sodium chloride $(3 \mathrm{~g})$ was added to avoid emulsion formation. Acetonitrile layer was collected and rotary evaporated and $20 \mathrm{~mL}$ of distilled water was added. This aqu- eous layer was liquid-liquid partitioned with hexane (25 $\mathrm{mL}, 3$ times). The hexane layer was removed completely and residue was dissolved in a small quantity of ethyl acetate and cleaned up by column chromatography using Florisil $(10 \mathrm{~g})$ and elution with $75 \mathrm{~mL}$ of hexane: ethyl acetate mixture $\left(9: 1 \mathrm{vv}^{-1}\right)$. The cleaned extracts obtained after the above chromatographic separations were quantified by reverse phase HPLC after taking it in acetonitrile.

\subsection{Recovery Experiment for Thiacloprid}

Untreated eggplant fruits $(50 \mathrm{~g})$ were spiked separately with 5, 25 and $50 \mu \mathrm{g}$ of thiacloprid and kept for $24 \mathrm{~h}$ before homogenization. Next day fortified samples were homogenized, extracted with $100 \mathrm{~mL}$ acetone, filtered through Whatman No. 1 filter paper and rotary evaporated at $40^{\circ} \mathrm{C}$ to remove acetone. The extracts were first liquid-liquid partitioned with hexane (10 $\mathrm{mL}, 3$ times) in a separatory funnel to remove interfering co-extractives and pigments. The liquid-liquid partitioning was redone using dichloromethane ( $25 \mathrm{~mL}, 3$ times), which was rotary evaporated and residues were dissolved in $5 \mathrm{~mL}$ of ethyl acetate: cyclohexane solution $\left(1: 1 \mathrm{vv}^{-1}\right)$. This organic extract was cleaned up by column chromatography using Florisil $(10 \mathrm{~g})$, sandwiched between two layers of sodium sulfate $(2 \mathrm{~g})$ in a glass column with $2 \mathrm{~cm}$ diameter. It was first eluted with $10 \mathrm{~mL}$ of ethyl acetate: cyclohexane solution $\left(1: 1 \mathrm{vv}^{-1}\right)$, followed by $50 \mathrm{~mL}$ of acetonitrile, which was collected and concentrated. The cleaned extract thus obtained after the above chromatographic separations were quantified by reverse phase HPLC.

\subsection{Recovery Experiment for Methyl Parathion}

Untreated eggplant fruits (chopped, $50 \mathrm{~g}$ ) were spiked separately to get $0.1,0.5$ and $1.0 \mathrm{mg} \cdot \mathrm{kg}^{-1}$ of methyl parathion on the fruit. The fortified samples were kept for 24 h. Extraction was done by blending in a mixer-blender for 2 minutes with $100 \mathrm{~mL}$ acetone. The contents were transferred into $250 \mathrm{~mL}$ conical flask. The jar was rinsed two times with acetone $(2 \times 40 \mathrm{~mL})$ and transferred into the flasks. The flasks were agitated on a mechanical shaker for 30 minutes. The supernatant liquid was then filtered under suction though Whatman No. 1 filter paper using Buchner funnel. The pooled extracts were concentrated using rotary evaporator to a minimum volume by distilling out the acetone. The remainder was transferred to $250 \mathrm{~mL}$ separatory funnel and $100 \mathrm{~mL}$ saturated aqueous sodium chloride solution was added to the contents. Then $75 \mathrm{~mL}$ of hexane was added and the contents were shaken vigorously for 2 minutes with intermittent release of pressure. After partitioning the contents were allowed 
to stand for 5 minutes. The upper layer i.e. hexane was collected in a conical flask after passing through activated anhydrous sodium sulphate. The left over aqueous layer was again partitioned twice with hexane $(2 \times 50$ $\mathrm{mL}$ ) following the same procedure. The hexane layers were pooled and concentrated to dryness using rotary vacuum evaporator. The residues were dissolved in 10 $\mathrm{mL}$ hexane-acetone mixture $(9: 1)$. Cleaned glass columns (60 $\mathrm{cm}$ long $\times 2 \mathrm{~cm}$ i.d.) were plugged at the bottom with cotton followed by addition of $5 \mathrm{~g}$ anhydrous sodium sulphate. Ten gram activated alumina (neutral) was poured over the layer of anhydrous sodium sulphate. Columns were tapped gently to have even packing. This packing was topped by small amount of cotton to avoid the disturbance of the alumina layer during addition of the solvent in the column. These columns were pre-washed with $25 \mathrm{~mL}$ solvent mixture (hexane-acetone, 9:1, $\mathrm{vv}^{-1}$ ) to remove the impurities and the leachate was discarded. The concentrated extracts obtained from partitioning processes were poured quantitatively in the packed columns. The columns were eluted with $100 \mathrm{~mL}$ hexane: acetone mixture $\left(9: 1, \mathrm{vv}^{-1}\right)$ which was collected in $250 \mathrm{~mL}$ conical flasks. The rate of elution was $3 \mathrm{~mL}$ minute $^{-1}$. The eluate thus collected was evaporated to dryness at $40^{\circ} \mathrm{C}$ in a round bottom flask with the help of a rotary evaporator. The remaining residue in the flask was dissolved in $5 \mathrm{~mL}$ hexane-acetone $(9: 1)$ mixture and transferred to 25 $\mathrm{mL}$ volumetric flasks and final volume was made up to the mark by using hexane-acetone (9:1) mixture for analysis by GLC.

\subsection{Weather Data}

During the period of the experiment in first year (2004) the minimum and maximum temperature varied between $13.3^{\circ} \mathrm{C}$ and $28.1^{\circ} \mathrm{C}$ respectively and mean relative humidity ranged from $58 \%-70 \%$. No rainfall was reported during the experiment. During second year (2005) the minimum and maximum temperature varied between $14.2^{\circ} \mathrm{C}$ and $29.3^{\circ} \mathrm{C}$, respectively and mean relative humidity ranged from $58 \%-68 \%$. There was no rainfall reported during the experiment.

\subsection{Statistical Analyses}

All the treatments were in Randomized Block Design (RBD) and taken in three replicates including untreated control. The data was analyzed using Statistica (Stat Soft) and Minitab 14.

\section{Results and Discussion}

\subsection{Dissipation of Indoxacarb}

The method involving Florisil gave highest average re- covery $(88 \%)$ of the pesticide when compared to other methods where average recoveries varied from 59\% to $82 \%$ (Table 1). Highest recovery by Florisil (synthetic magnesium silicate) can be attributed to the fact that it is less reactive than alumina or silicagel in retaining the insecticide where as low recoveries on using charcoal were due to its high adsorptive power. The mean initial deposits of indoxacarb on eggplant fruits were 2.60 to $3.64 \mathrm{mg} \cdot \mathrm{kg}^{-1}$ and 2.63 to $3.68 \mathrm{mg} \cdot \mathrm{kg}^{-1}$ from 75 and 150 $\mathrm{g} \cdot \mathrm{ai} \cdot \mathrm{ha}^{-1}$ treatments from first and second year field trials, respectively (Tables 2 and 3 ). The reported concentration declined with time and reached non-detectable $(<0.02$ $\mathrm{mg} \cdot \mathrm{kg}^{-1}$ ) after 15 - 20 days (Figure 1). Residues dissipated with half-life of $3.0-3.8 \mathrm{~d}$ from both first and second year sprays, respectively. There was no significant difference in dissipation pattern between the two rates of applications suggesting that the dissipation of indoxacarb was independent of the dose of insecticide. The residue concentration data fitted to a first order rate kinetics [23] and dissipation rate constants ranged from 0.090 and 0.133 for 75 and $150 \mathrm{~g} \cdot$ ai $^{\prime} \cdot$ ha $^{-1}$ treatments, respectively (Table 8).

The Theoretical Maximum Daily Intake (TMDI) for first year from maximum residues observed for first day for both the treatments was found to be 0.446 to 0.643 $\mathrm{mg} \cdot$ person $^{-1} \cdot$ day $^{-1}$ which is near the Maximum Permissible Intake (MPI) of $0.6 \mathrm{mg} \cdot$ person $^{-1} \cdot$ day $^{-1}[24,25]$. The TMDI was calculated considering recommended consumption of vegetables as $200 \mathrm{~g}$ for leafy or fruit vegetables other than roots and tubers [26,27] and MPI was calculated on the basis of ADI value of indoxacarb 0.01 $\mathrm{mg} \cdot \mathrm{kg}^{-1}$ body weight [28] and the average body weight of an average person was taken as $60 \mathrm{~kg}$. Eggplant fruits are harvested frequently but first picking is intentionally done at least one $\mathrm{d}$ after the application of an insecticide. On the first day TMDI was more than MPI. The TMDI from $3 \mathrm{~d}$ residues was found to be less than the MPI (0.6 $\mathrm{mg} \cdot$ person $^{-1} \cdot$ day $^{-1}$ ) calculated with the data of $3 \mathrm{~d}$ residues. This encompasses more margin of safety (MOS). In view of this a minimum of $3 \mathrm{~d}$ waiting period for harvest of fruits after insecticide application and processing is recommended to achieve maximum safety and minimum risk to consumers. Taking $0.5 \mathrm{mg} \cdot \mathrm{kg}^{-1} \mathrm{MRL}$ of indoxacarb on vegetables [28,29] for eggplant, a practical waiting period can be proposed, which can be practiced by the farmers.

\subsection{Dissipation of Thiacloprid}

The method involving Florisil gave highest average recovery $(89 \%)$ of the pesticide when compared to other adsorbents, where average recoveries varied from $61 \%$ to $83 \%$ (Table 1). Neutral alumina and silicagel also gave satisfactory percent recoveries i.e., 83 and 80 , respectively. The mean initial deposits of thiacloprid on eggplant fruits 
Table 1. Recovery of indoxacarb, thiacloprid and methyl parathion from eggplant fruits.

\begin{tabular}{|c|c|c|c|c|c|c|c|}
\hline \multirow[b]{2}{*}{$\begin{array}{l}\text { Adsorbent } \\
\text { Used }\end{array}$} & \multirow[b]{2}{*}{$\begin{array}{c}\text { Fortification } \\
\text { Level }\left(\mathrm{mg} \cdot \mathrm{kg}^{-1}\right)\end{array}$} & \multicolumn{2}{|c|}{ Indoxacarb } & \multicolumn{2}{|c|}{ Thiacloprid } & \multicolumn{2}{|c|}{ Methyl Parathion } \\
\hline & & $\begin{array}{c}\text { Mean Amount } \\
\text { Recovered }\left(\mathrm{mg} \cdot \mathrm{kg}^{-1}\right)\end{array}$ & $\begin{array}{c}\text { Average } \\
\text { Recovery (\%) }\end{array}$ & $\begin{array}{c}\text { Mean Amount } \\
\text { Recovered }\left(\mathrm{mg} \cdot \mathrm{kg}^{-1}\right)\end{array}$ & $\begin{array}{c}\text { Average } \\
\text { Recovery (\%) }\end{array}$ & $\begin{array}{c}\text { Mean Amount } \\
\text { recovered }\left(\mathrm{mg} \cdot \mathrm{kg}^{-1}\right)\end{array}$ & $\begin{array}{c}\text { Average } \\
\text { Recovery (\%) }\end{array}$ \\
\hline \multirow{3}{*}{ Florisil } & 0.1 & 0.09 & \multirow{3}{*}{88} & 0.09 & \multirow{3}{*}{89} & 0.09 & \multirow{3}{*}{89} \\
\hline & 0.5 & 0.43 & & 0.44 & & 0.44 & \\
\hline & 1.0 & 0.89 & & 0.90 & & 0.9 & \\
\hline \multirow{3}{*}{ Alumina $(\mathrm{N})^{*}$} & 0.1 & 0.08 & \multirow{3}{*}{82} & 0.08 & \multirow{3}{*}{82} & 0.09 & \multirow{3}{*}{86} \\
\hline & 0.5 & 0.42 & & 0.43 & & 0.42 & \\
\hline & 1.0 & 0.81 & & 0.81 & & 0.85 & \\
\hline \multirow{3}{*}{ Silica Gel } & 0.1 & 0.08 & \multirow{3}{*}{79} & 0.08 & \multirow{3}{*}{81} & 0.09 & \multirow{3}{*}{87} \\
\hline & 0.5 & 0.39 & & 0.40 & & 0.43 & \\
\hline & 1.0 & 0.80 & & 0.82 & & 0.84 & \\
\hline \multirow{3}{*}{$\begin{array}{l}\text { Magnesium } \\
\text { Oxide }\end{array}$} & 0.1 & 0.07 & \multirow{3}{*}{73} & 0.08 & \multirow{3}{*}{77} & 0.08 & \multirow{3}{*}{76} \\
\hline & 0.5 & 0.38 & & 0.38 & & 0.37 & \\
\hline & 1.0 & 0.72 & & 0.75 & & 0.75 & \\
\hline \multirow{3}{*}{$\begin{aligned} \text { Florisil } \\
+ \text { Charcoal } \\
(2 \%)\end{aligned}$} & 0.1 & 0.07 & \multirow{3}{*}{68} & 0.07 & \multirow{3}{*}{70} & 0.07 & \multirow{3}{*}{71} \\
\hline & 0.5 & 0.34 & & 0.35 & & 0.35 & \\
\hline & 1.0 & 0.66 & & 0.69 & & 0.72 & \\
\hline \multirow{3}{*}{$\begin{array}{c}\text { Alumina }(\mathrm{N}) \\
+ \text { Charcoal } \\
(2 \%)\end{array}$} & 0.1 & 0.06 & \multirow{3}{*}{63} & 0.07 & \multirow{3}{*}{69} & 0.06 & \multirow{3}{*}{62} \\
\hline & 0.5 & 0.32 & & 0.34 & & 0.32 & \\
\hline & 1.0 & 0.64 & & 0.68 & & 0.62 & \\
\hline \multirow{3}{*}{$\begin{array}{c}\text { Silica gel } \\
+ \text { Charcoal } \\
(2 \%)\end{array}$} & 0.1 & 0.06 & \multirow{3}{*}{61} & 0.07 & \multirow{3}{*}{68} & 0.07 & \\
\hline & 0.5 & 0.30 & & 0.34 & & 0.34 & 67 \\
\hline & 1.0 & 0.63 & & 0.66 & & 0.64 & \\
\hline & 0.1 & 0.06 & & 0.06 & & 0.06 & \\
\hline Charcoal & 0.5 & 0.29 & 59 & 0.32 & 61 & 0.31 & 62 \\
\hline & 1.0 & 0.58 & & 0.60 & & 0.63 & \\
\hline
\end{tabular}

*Alumina (neutral)

Table 2. Persistence of indoxacarb residues from eggplant fruits: first year.

\begin{tabular}{|c|c|c|c|c|c|c|c|c|c|c|}
\hline \multirow{3}{*}{$\begin{array}{l}\text { Time after } \\
\text { application } \\
\text { (days) }\end{array}$} & \multicolumn{10}{|c|}{ Treatment level } \\
\hline & \multicolumn{5}{|c|}{$75 \mathrm{~g} \cdot \mathrm{ai} \cdot \mathrm{ha}^{-1}$ Residues $\left(\mathrm{mg} \cdot \mathrm{kg}^{-1}\right.$ ) } & \multicolumn{5}{|c|}{$150 \mathrm{~g} \cdot \mathrm{ai} \cdot \mathrm{ha}^{-1}$ Residues $\left(\mathrm{mg} \cdot \mathrm{kg}^{-1}\right)$} \\
\hline & $\mathrm{R}_{1}$ & $\mathrm{R}_{2}$ & $\mathrm{R}_{3}$ & Mean & Per cent loss & $\mathrm{R}_{1}$ & $\mathrm{R}_{2}$ & $\mathrm{R}_{3}$ & Mean & Per cent loss \\
\hline 0 & 2.436 & 2.589 & 2.771 & $\begin{array}{c}2.599 \\
( \pm 0.168)^{*}\end{array}$ & - & 3.886 & 3.585 & 3.447 & $\begin{array}{c}3.639 \\
( \pm 0.224)\end{array}$ & - \\
\hline 1 & 2.134 & 2.168 & 2.279 & $\begin{array}{c}2.194 \\
( \pm 0.076)\end{array}$ & 15.60 & 3.143 & 2.965 & 3.125 & $\begin{array}{c}3.078 \\
( \pm 0.098)\end{array}$ & 15.43 \\
\hline 3 & 0.986 & 1.214 & 1.129 & $\begin{array}{c}1.110 \\
( \pm 0.115)\end{array}$ & 57.30 & 2.074 & 1.943 & 1.982 & $\begin{array}{c}2.000 \\
( \pm 0.067)\end{array}$ & 45.05 \\
\hline 5 & 0.783 & 0.791 & 0.804 & $\begin{array}{c}0.793 \\
( \pm 0.011)\end{array}$ & 69.50 & 1.236 & 1.364 & 1.287 & $\begin{array}{c}1.296 \\
( \pm 0.064)\end{array}$ & 64.39 \\
\hline 7 & 0.421 & 0.563 & 0.586 & $\begin{array}{c}0.523 \\
( \pm 0.089)\end{array}$ & 79.86 & 0.765 & 0.731 & 0.755 & $\begin{array}{c}0.750 \\
( \pm 0.017)\end{array}$ & 79.38 \\
\hline 10 & 0.324 & 0.312 & 0.275 & $\begin{array}{c}0.304 \\
( \pm 0.026)\end{array}$ & 88.32 & 0.388 & 0.342 & 0.347 & $\begin{array}{c}0.359 \\
( \pm 0.025)\end{array}$ & 90.13 \\
\hline 15 & 0.143 & 0.095 & 0.084 & $\begin{array}{c}0.107 \\
( \pm 0.031)\end{array}$ & 95.87 & 0.139 & 0.128 & 0.136 & $\begin{array}{c}0.134 \\
( \pm 0.006)\end{array}$ & 96.31 \\
\hline 20 & ND & ND & ND & - & - & 0.033 & 0.042 & 0.048 & $\begin{array}{c}0.041 \\
( \pm 0.008)\end{array}$ & 98.87 \\
\hline 25 & ND & ND & ND & - & - & ND & ND & ND & - & - \\
\hline
\end{tabular}

$\mathrm{ND}=$ Non detectable $;{ }^{*}=$ Standard deviation. 
(Solanum melongena L.) and Pesticide Residue Dissipation Pattern

Table 3. Persistence of indoxacarb residues from eggplant fruits: second year.

\begin{tabular}{|c|c|c|c|c|c|c|c|c|c|c|}
\hline \multirow{3}{*}{$\begin{array}{l}\text { Time after } \\
\text { application } \\
\text { (days) }\end{array}$} & \multicolumn{10}{|c|}{ Treatment level } \\
\hline & \multicolumn{5}{|c|}{$75 \mathrm{~g} \cdot$ ai $\cdot \mathrm{ha}^{-1}$ Residues $\left(\mathrm{mg} \cdot \mathrm{kg}^{-1}\right)$} & \multicolumn{5}{|c|}{$150 \mathrm{~g} \cdot \mathrm{ai} \cdot \mathrm{ha}^{-1}$ Residues $\left(\mathrm{mg} \cdot \mathrm{kg}^{-1}\right)$} \\
\hline & $\mathrm{R}_{1}$ & $\mathrm{R}_{2}$ & $\mathrm{R}_{3}$ & Mean & Per cent loss & $\mathrm{R}_{1}$ & $\mathrm{R}_{2}$ & $\mathrm{R}_{3}$ & Mean & Per cent loss \\
\hline 0 & 2.662 & 2.612 & 2.629 & $\begin{array}{c}2.634 \\
( \pm 0.025)^{*}\end{array}$ & - & 3.913 & 3.606 & 3.512 & $\begin{array}{c}3.677 \\
( \pm 0.210)\end{array}$ & - \\
\hline 1 & 2.234 & 2.185 & 2.279 & $\begin{array}{c}2.233 \\
( \pm 0.047)\end{array}$ & 15.24 & 3.164 & 2.992 & 3.215 & $\begin{array}{c}3.124 \\
( \pm 0.117)\end{array}$ & 15.05 \\
\hline 3 & 0.975 & 1.345 & 1.214 & $\begin{array}{c}1.178 \\
( \pm 0.188)\end{array}$ & 55.28 & 2.115 & 2.041 & 2.012 & $\begin{array}{c}2.056 \\
( \pm 0.053)\end{array}$ & 44.08 \\
\hline 5 & 0.763 & 0.806 & 0.833 & $\begin{array}{c}0.801 \\
( \pm 0.035)\end{array}$ & 69.60 & 1.265 & 1.392 & 1.263 & $\begin{array}{c}1.307 \\
( \pm 0.074)\end{array}$ & 64.46 \\
\hline 7 & 0.431 & 0.587 & 0.613 & $\begin{array}{c}0.544 \\
( \pm 0.098)\end{array}$ & 79.36 & 0.809 & 0.768 & 0.794 & $\begin{array}{c}0.790 \\
( \pm 0.021)\end{array}$ & 78.51 \\
\hline 10 & 0.362 & 0.349 & 0.304 & $\begin{array}{c}0.338 \\
( \pm 0.030)\end{array}$ & 87.16 & 0.412 & 0.373 & 0.361 & $\begin{array}{c}0.382 \\
( \pm 0.027)\end{array}$ & 89.61 \\
\hline 15 & 0.156 & 0.087 & 0.107 & $\begin{array}{c}0.117 \\
( \pm 0.036)\end{array}$ & 95.57 & 0.127 & 0.137 & 0.119 & $\begin{array}{c}0.128 \\
( \pm 0.009)\end{array}$ & 96.53 \\
\hline 20 & ND & ND & ND & - & - & 0.052 & 0.064 & 0.048 & $\begin{array}{c}0.055 \\
( \pm 0.008)\end{array}$ & 98.51 \\
\hline 25 & ND & ND & ND & - & - & ND & $\mathrm{ND}$ & $\mathrm{ND}$ & $\begin{array}{c}- \\
-\end{array}$ & - \\
\hline
\end{tabular}

$\mathrm{ND}=$ Non detectable $;{ }^{*}=$ Standard deviation.

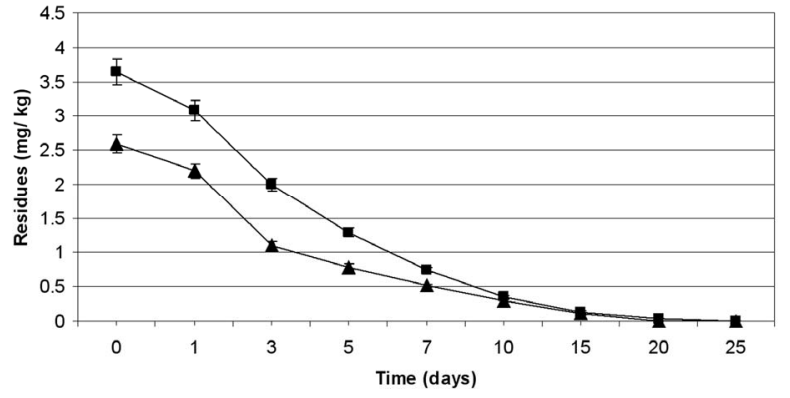

(a)

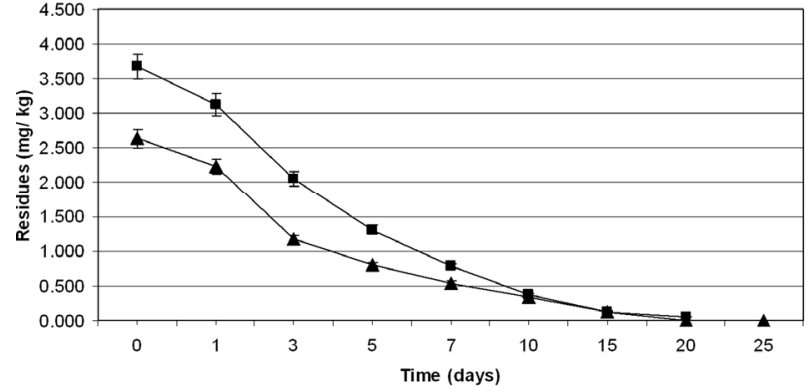

(b)

Figure 1. Persistence of indoxacarb residues from eggplant fruits: first year (a) and second year (b) at treatment levels 75 $\mathrm{g} \cdot \mathrm{ai}^{\cdot} \cdot \mathrm{ha}^{-1}(\square)$ and $150 \mathrm{~g} \cdot \mathrm{ai} \cdot \mathrm{ha}^{-1}(\Delta)$. Vertical bars represent standard deviation $(\mathrm{n}=3)$.

were 3.39 to $5.40 \mathrm{mg} \cdot \mathrm{kg}^{-1}$ and 3.40 to $5.39 \mathrm{mg} \cdot \mathrm{kg}^{-1}$ from 30 and $60 \mathrm{~g} \cdot \mathrm{ai} \cdot \mathrm{ha}^{-1}$ treatments from first and second year field trails, respectively (Tables 4 and 5). The reported concentration declined with time but did not reach non-detectable $\left(<0.01 \mathrm{mg} \cdot \mathrm{kg}^{-1}\right)$ even after $20 \mathrm{~d}$. (Figure 2). Residues dissipated with half-life of 11.1 and $11.6 \mathrm{~d}$ from both first and second year sprays, respectively (Table 8). There was no significant difference in dissipation pattern between the two rates of applications suggesting that the dissipation of thiacloprid was not dependent on the dose of insecticide applied. The residue concentration data fitted to a first order rate kinetics [30] and the dissipation rate constants ranged from 0.117 and 0.199 for 30 and $60 \mathrm{~g} \cdot \mathrm{ai} \cdot \mathrm{ha}^{-1}$ treatments for both years.

The TMDI from maximum residues observed for first day for both the treatments during first year trials was found to be 0.682 to $1.098 \mathrm{mg} \cdot$ person $^{-1} \cdot$ day $^{-1}$ which is not lower than the MPI of $0.72 \mathrm{mg} \cdot$ person $^{-1} \cdot$ day $^{-1}$. The TMDI was calculated considering recommended consumption of vegetables as $200 \mathrm{~g}$ for leafy or fruit vegeta- bles [26,27] and MPI was calculated on the basis of ADI value of thiacloprid $0.012 \mathrm{mg} \cdot \mathrm{kg}^{-1}$ body weight [29] and the average body weight of an average person was taken as $60 \mathrm{~kg}$. Eggplant fruits are normally harvested frequently but first picking is intentionally done one to three day after the spray of an insecticide. Considering this, $3 \mathrm{~d}$ residues were also examined. The TMDI even from $3 \mathrm{~d}$ residues for recommended dose i.e. $30 \mathrm{~g} \cdot \mathrm{ai} \cdot \mathrm{ha}^{-1}$ was not found less than the MPI value. There is a need for higher MOS when thiacloprid is applied on eggplant in the recommended dose. In view of this, $3 \mathrm{~d}$ waiting period for harvest of fruits after insecticide application cannot be suggested unless the fruits are decontaminated before consumption. Taking $0.02 \mathrm{mg} \cdot \mathrm{kg}^{-1} \mathrm{MRL}$ of thiacloprid on vegetables (onion) $[31,32]$ a waiting period of more than $20 \mathrm{~d}$ is needed, even for smallest dose i.e., 30 $\mathrm{g} \cdot \mathrm{ai} \cdot \mathrm{ha}^{-1}$, which is not practical for the farmers. This large waiting period may be attributed to the systemic nature of thiacloprid. Hence this insecticide cannot be included in good agricultural practice for growing eggplant. The 
Table 4. Persistence of thiacloprid residues on eggplant fruits: first year.

\begin{tabular}{|c|c|c|c|c|c|c|c|c|c|c|}
\hline \multirow{3}{*}{$\begin{array}{l}\text { Time after } \\
\text { application } \\
\text { (days) }\end{array}$} & \multicolumn{10}{|c|}{ Treatment level } \\
\hline & \multicolumn{5}{|c|}{$30 \mathrm{~g} \cdot \mathrm{ai} \cdot \mathrm{ha}^{-1}$ Residues $\left(\mathrm{mg} \cdot \mathrm{kg}^{-1}\right)$} & \multicolumn{5}{|c|}{$60 \mathrm{~g} \cdot \mathrm{ai} \cdot \mathrm{ha}^{-1}$ Residues $\left(\mathrm{mg} \cdot \mathrm{kg}^{-1}\right)$} \\
\hline & $\mathrm{R}_{1}$ & $\mathrm{R}_{2}$ & $\mathrm{R}_{3}$ & Mean & Per cent loss & $\mathrm{R}_{1}$ & $\mathrm{R}_{2}$ & $\mathrm{R}_{3}$ & Mean & Per cent loss \\
\hline 0 & 3.356 & 3.398 & 3.412 & $\begin{array}{c}3.389 \\
( \pm 0.029)^{*}\end{array}$ & - & 5.366 & 5.488 & 5.352 & $\begin{array}{c}5.402 \\
( \pm 0.075)\end{array}$ & - \\
\hline 1 & 2.965 & 2.867 & 2.922 & $\begin{array}{c}2.918 \\
( \pm 0.049)\end{array}$ & 13.90 & 4.845 & 4.861 & 4.731 & $\begin{array}{c}4.812 \\
( \pm 0.071)\end{array}$ & 10.92 \\
\hline 3 & 2.613 & 2.591 & 2.638 & $\begin{array}{c}2.614 \\
( \pm 0.024)\end{array}$ & 22.87 & 4.383 & 4.422 & 4.337 & $\begin{array}{c}4.381 \\
( \pm 0.043)\end{array}$ & 18.91 \\
\hline 5 & 2.313 & 2.388 & 2.411 & $\begin{array}{c}2.371 \\
( \pm 0.051)\end{array}$ & 30.05 & 3.862 & 3.853 & 3.813 & $\begin{array}{c}3.843 \\
( \pm 0.026)\end{array}$ & 28.87 \\
\hline 7 & 2.131 & 2.014 & 2.058 & $\begin{array}{c}2.068 \\
( \pm 0.059)\end{array}$ & 38.99 & 3.323 & 3.543 & 3.286 & $\begin{array}{c}3.384 \\
( \pm 0.139)\end{array}$ & 37.36 \\
\hline 10 & 1.786 & 1.825 & 1.759 & $\begin{array}{c}1.790 \\
( \pm 0.033)\end{array}$ & 47.18 & 2.785 & 2.763 & 2.745 & $\begin{array}{c}2.764 \\
( \pm 0.020)\end{array}$ & 48.83 \\
\hline 15 & 1.345 & 1.387 & 1.423 & $\begin{array}{c}1.385 \\
( \pm 0.039)\end{array}$ & 59.13 & 2.135 & 1.956 & 1.984 & $\begin{array}{c}2.025 \\
( \pm 0.096)\end{array}$ & 62.51 \\
\hline 20 & 0.966 & 0.985 & 0.954 & $\begin{array}{c}0.968 \\
( \pm 0.016) \\
\end{array}$ & 71.43 & 1.256 & 1.362 & 1.315 & $\begin{array}{c}1.311 \\
( \pm 0.053) \\
\end{array}$ & 75.73 \\
\hline
\end{tabular}

* $=$ Standard deviation.

Table 5. Persistence of thiacloprid residues on eggplant fruits: second year.

\begin{tabular}{|c|c|c|c|c|c|c|c|c|c|c|}
\hline \multirow{3}{*}{$\begin{array}{l}\text { Time after } \\
\text { application } \\
\text { (days) }\end{array}$} & \multicolumn{10}{|c|}{ Treatment level } \\
\hline & \multicolumn{5}{|c|}{$30 \mathrm{~g} \cdot \mathrm{ai} \cdot \mathrm{ha}^{-1}$ Residues $\left(\mathrm{mg} \cdot \mathrm{kg}^{-1}\right)$} & \multicolumn{5}{|c|}{$60 \mathrm{~g} \cdot \mathrm{ai} \cdot \mathrm{ha}^{-1}$ Residues $\left(\mathrm{mg} \cdot \mathrm{kg}^{-1}\right)$} \\
\hline & $\mathrm{R}_{1}$ & $\mathrm{R}_{2}$ & $\mathrm{R}_{3}$ & Mean & Per cent loss & $\mathrm{R}_{1}$ & $\mathrm{R}_{2}$ & $\mathrm{R}_{3}$ & Mean & Per cent loss \\
\hline 0 & 3.378 & 3.362 & 3.458 & $\begin{array}{c}3.399 \\
( \pm 0.051)^{*}\end{array}$ & - & 5.389 & 5.461 & 5.333 & $\begin{array}{c}5.394 \\
( \pm 0.064)\end{array}$ & - \\
\hline 1 & 2.959 & 2.838 & 2.949 & $\begin{array}{c}2.915 \\
( \pm 0.067)\end{array}$ & 14.23 & 4.863 & 4.882 & 4.756 & $\begin{array}{c}4.834 \\
( \pm 0.068)\end{array}$ & 10.39 \\
\hline 5 & 2.333 & 2.364 & 2.429 & $\begin{array}{c}2.375 \\
( \pm 0.049)\end{array}$ & 30.12 & 3.852 & 3.871 & 3.836 & $\begin{array}{c}3.853 \\
( \pm 0.018)\end{array}$ & 28.57 \\
\hline 7 & 2.147 & 2.089 & 2.106 & $\begin{array}{c}2.114 \\
( \pm 0.030)\end{array}$ & 37.81 & 3.337 & 3.575 & 3.231 & $\begin{array}{c}3.381 \\
( \pm 0.176)\end{array}$ & 37.32 \\
\hline 10 & 1.752 & 1.838 & 1.777 & $\begin{array}{c}1.789 \\
( \pm 0.044)\end{array}$ & 47.37 & 2.799 & 2.734 & 2.773 & $\begin{array}{c}2.769 \\
( \pm 0.033)\end{array}$ & 48.67 \\
\hline 20 & 0.929 & 0.937 & 0.968 & $\begin{array}{c}0.945 \\
( \pm 0.021)\end{array}$ & 72.21 & 1.287 & 1.373 & 1.366 & $\begin{array}{c}1.342 \\
( \pm 0.048)\end{array}$ & 75.12 \\
\hline
\end{tabular}

${ }^{*}=$ Standard deviation.

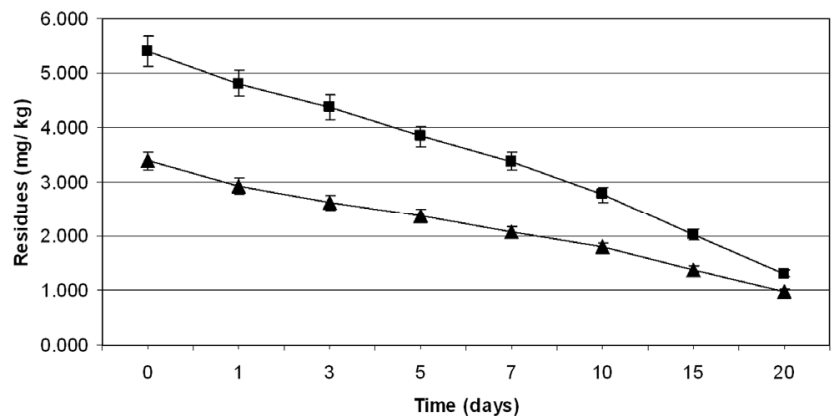

(a)

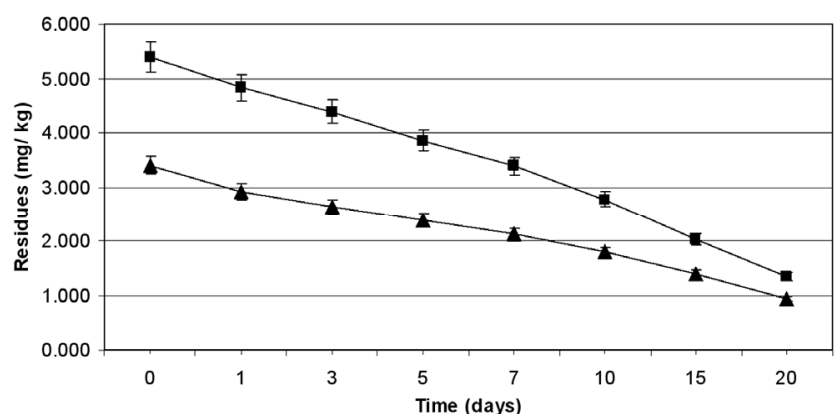

(b)

Figure 2. Persistence of thiacloprid residues from eggplant fruits: first year (a) and second year (b) at treatment levels 30 $\mathrm{g} \cdot \mathrm{ai}^{\circ} \cdot \mathrm{ha}^{-1}(\square)$ and $60 \mathrm{~g} \cdot \mathrm{ai} \cdot \mathrm{ha}^{-1}(\Delta)$. Vertical bars represent standard deviation $(\mathrm{n}=3)$. 
MRL of $0.7 \mathrm{mg} \cdot \mathrm{kg}^{-1}$ for thiacloprid under consideration by Codex eggplant has been questioned [33].

\subsection{Dissipation of Methyl Parathion}

The method involving Florisil gave highest average recovery $(89 \%)$ of the pesticide when compared to other methods where average recoveries varied from $62 \%$ to $87 \%$ (Table 1). Neutral alumina and silica gel also gave satisfactory per cent recoveries i.e., 86 and 87 , respecttively. The initial residues on eggplant fruits from recommended dose declined from 3.60 to $3.12 \mathrm{mg} \cdot \mathrm{kg}^{-1}$ in one day and $0.27 \mathrm{mg} \cdot \mathrm{kg}^{-1}$ in twenty five days from lower rates of treatment i.e. $100 \mathrm{~g} \cdot \mathrm{ai} \cdot \mathrm{ha}^{-1}$ (Table 6). Similarly in the case of $200 \mathrm{~g} \cdot \mathrm{ai} \cdot \mathrm{ha}^{-1}$ treatment, the initial deposits declined from 4.02 to $0.34 \mathrm{mg} \cdot \mathrm{kg}^{-1}$ in 25 days, respecttively (Table 7). The residue data exhibited similar pattern in second year also (Figure 3).

Table 6. Persistence of methyl parathion residues from eggplant fruits: first year.

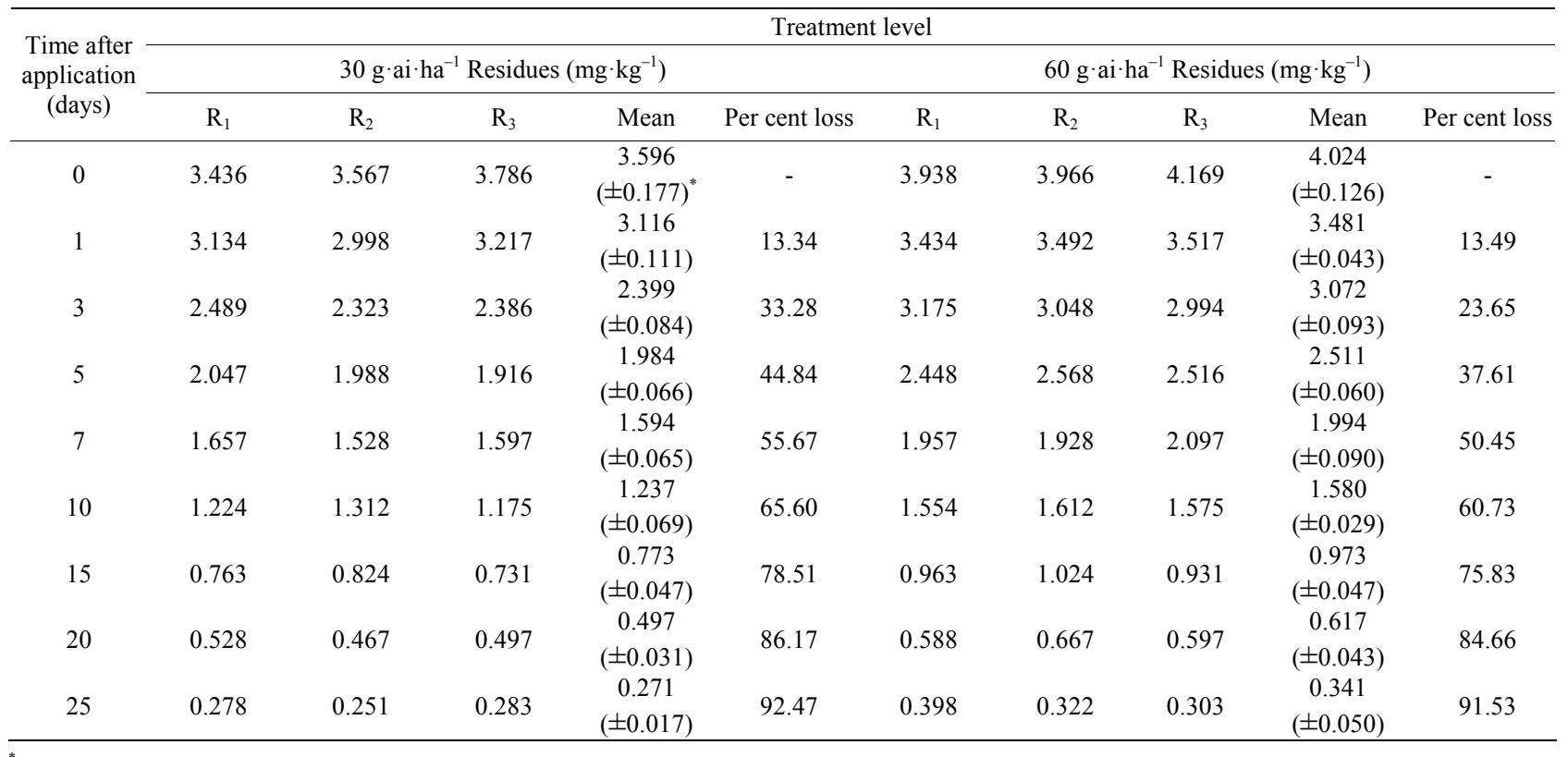

${ }^{*}=$ Standard deviation.

Table 7. Persistence of methyl parathion residues from eggplant fruits: second year.

\begin{tabular}{|c|c|c|c|c|c|c|c|c|c|c|}
\hline \multirow{3}{*}{$\begin{array}{l}\text { Time after } \\
\text { application } \\
\text { (days) }\end{array}$} & \multicolumn{10}{|c|}{ Treatment level } \\
\hline & \multicolumn{5}{|c|}{$30 \mathrm{~g} \cdot \mathrm{ai} \cdot \mathrm{ha}^{-1}$ Residues $\left(\mathrm{mg} \cdot \mathrm{kg}^{-1}\right)$} & \multicolumn{5}{|c|}{$60 \mathrm{~g} \cdot \mathrm{ai} \cdot \mathrm{ha}^{-1}$ Residues $\left(\mathrm{mg} \cdot \mathrm{kg}^{-1}\right)$} \\
\hline & $\mathrm{R}_{1}$ & $\mathrm{R}_{2}$ & $\mathrm{R}_{3}$ & Mean & Per cent loss & $\mathrm{R}_{1}$ & $\mathrm{R}_{2}$ & $\mathrm{R}_{3}$ & Mean & Per cent loss \\
\hline 0 & 3.478 & 3.592 & 3.805 & $\begin{array}{c}3.625 \\
( \pm 0.166)^{*}\end{array}$ & & 4.097 & 3.895 & 4.117 & $\begin{array}{c}4.036 \\
( \pm 0.123)\end{array}$ & \\
\hline 1 & 3.172 & 3.122 & 3.269 & $\begin{array}{c}3.188 \\
( \pm 0.075)\end{array}$ & 12.06 & 3.524 & 3.512 & 3.564 & $\begin{array}{c}3.533 \\
( \pm 0.027)\end{array}$ & 12.45 \\
\hline 3 & 2.524 & 2.421 & 2.437 & $\begin{array}{c}2.461 \\
( \pm 0.055)\end{array}$ & 32.12 & 3.194 & 3.115 & 3.057 & $\begin{array}{c}3.122 \\
( \pm 0.069)\end{array}$ & 22.65 \\
\hline 5 & 2.103 & 2.058 & 1.964 & $\begin{array}{c}2.042 \\
( \pm 0.071)\end{array}$ & 43.68 & 2.487 & 2.591 & 2.566 & $\begin{array}{c}2.548 \\
( \pm 0.054)\end{array}$ & 36.87 \\
\hline 7 & 1.682 & 1.581 & 1.613 & $\begin{array}{c}1.625 \\
( \pm 0.052)\end{array}$ & 55.16 & 2.132 & 1.975 & 2.042 & $\begin{array}{c}2.050 \\
( \pm 0.079)\end{array}$ & 49.22 \\
\hline 10 & 1.274 & 1.354 & 1.225 & $\begin{array}{c}1.284 \\
( \pm 0.065)\end{array}$ & 64.57 & 1.596 & 1.667 & 1.613 & $\begin{array}{c}1.625 \\
( \pm 0.037)\end{array}$ & 59.73 \\
\hline 15 & 0.778 & 0.843 & 0.794 & $\begin{array}{c}0.805 \\
( \pm 0.034)\end{array}$ & 77.79 & 0.992 & 1.102 & 0.983 & $\begin{array}{c}1.026 \\
( \pm 0.066)\end{array}$ & 74.59 \\
\hline 20 & 0.552 & 0.493 & 0.517 & $\begin{array}{c}0.521 \\
( \pm 0.030)\end{array}$ & 85.64 & 0.603 & 0.678 & 0.623 & $\begin{array}{c}0.635 \\
( \pm 0.039)\end{array}$ & 84.27 \\
\hline 25 & 0.265 & 0.288 & 0.313 & $\begin{array}{c}0.289 \\
( \pm 0.024)\end{array}$ & 92.04 & 0.422 & 0.368 & 0.337 & $\begin{array}{c}0.376 \\
( \pm 0.043)\end{array}$ & 90.69 \\
\hline
\end{tabular}

\footnotetext{
${ }^{*}=$ Standard deviation.
} 


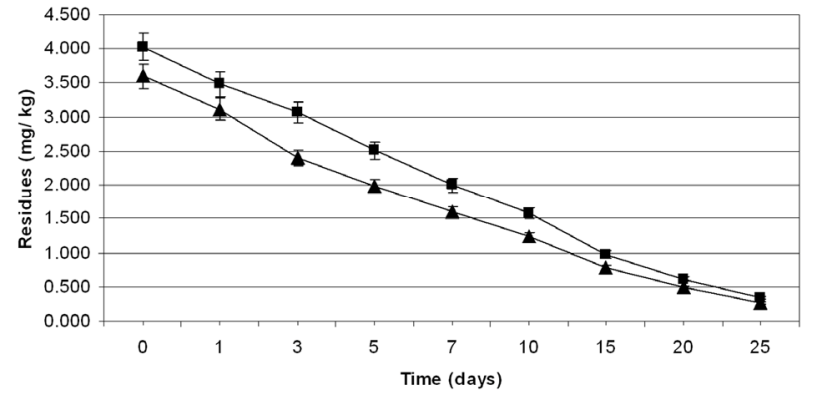

(a)

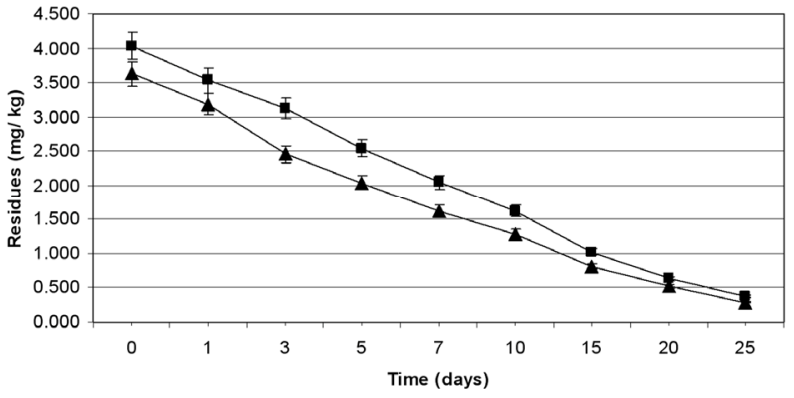

(b)

Figure 3. Persistence of methyl parathion residues from eggplant fruits: first year (a) and second year (b) at treatment levels $100 \mathrm{~g} \cdot \mathrm{ai} \cdot \mathrm{ha}^{-1}(\square)$ and $200 \mathrm{~g} \cdot \mathrm{ai} \cdot \mathrm{ha}^{-1}(\Delta)$. Vertical bars represent standard deviation $(\mathrm{n}=3)$.

Here also, there was no significant difference in dissipation pattern among the two treatments suggesting that the dissipation was independent of initial concentration. The residue data of methyl parathion when plotted for $\log$ residues versus time, fitted to a first order rate kinetics $\mathrm{Y}=\mathrm{C}-\mathrm{mX}$, where " $\mathrm{Y}$ " is the logarithmic deposition of methyl parathion on eggplant fruits at time zero, " $\mathrm{m}$ " is the dissipation rate constant/slope of the regression line and " $\mathrm{X}$ " is the time in days. The dissipation rate constants were 0.123 and 0.140 for 100 and $200 \mathrm{~g} \cdot \mathrm{ai} \cdot \mathrm{ha}^{-1}$ treatments, respectively and the half life values ranged from 6.0 to 7.4 days (Table 8). The correlation coefficient values of -0.933 and -0.959 denotes that the data are significant. In the case of second year spray, the dissipation rate constants were 0.125 and 0.143 , while the half life values were 6.02 and 7.39 days for 100 and 200 $\mathrm{g} \cdot \mathrm{ai} \cdot \mathrm{ha}^{-1}$ treatments, respectively and the values of correlation coefficient $(-0.936$ and -0.959$)$ showed that the data is significant.

The MRL of methyl parathion on eggplant fruit is not available in India. However, FAO/WHO [34] has assigned $0.2 \mathrm{mg} \cdot \mathrm{kg}^{-1} \mathrm{MRL}$ on vegetable (Tomato). If this value is extended for eggplant, it would be seen (Figure 3; Table 8) that the residues were safe after 20 days from application of lower dose $\left(100 \mathrm{~g} \cdot \mathrm{ai} \cdot \mathrm{ha}^{-1}\right)$. In the case of higher dose $\left(200 \mathrm{~g} \cdot \mathrm{ai} \cdot \mathrm{ha}^{-1}\right)$, the residues reached at a safe level after 25 days. Therefore, there should be a minimum gap of 20 days after the last application of the insecticide to the harvest, which is impractical. This emphasizes the importance of decontamination of fruits and vegetables. This pesticide gives effective control of pest but has adverse residue profile. The prescribed acceptable daily intake (ADI) for methyl parathion is 0.02 $\mathrm{mg} \cdot \mathrm{kg}^{-1}$ body weight. Considering the average body weight of an Indian as $60 \mathrm{~kg}$, the maximum permissible intake (MPI) was calculated to be $1.2 \mathrm{mg} \cdot$ person $^{-1} \cdot \mathrm{day}^{-1}$. The recommended vegetable in the balanced diet of an adult man is $200 \mathrm{~g}$ [26].

Residue data on eggplant showed that maximum residues were found on zero day samples and TMRC was calculated, based on $200 \mathrm{~g}$ eggplant fruits consumption and the residues encountered on zero day contaminated samples for all the treatments, by the following formula, TMRC $=$ Residue level $\times$ Food factor $\times$ Daily food intake. The TMRC values ranged from 0.687 to $0.834 \mathrm{mg} \cdot$ per$\mathrm{son}^{-1} \cdot$ day $^{-1}$ from eggplant. From the data, it was noticed that the calculated TMRC values were near the MPI value $\left(1.2 \mathrm{mg} \cdot\right.$ person $\left.^{-1} \cdot \mathrm{day}^{-1}\right)$ as this organophosphorus insecticide is applied in other crops as well. Methyl parathion $\left(\mathrm{LD}_{50}\right.$ male rat $\left.6-50 \mathrm{mg} \cdot \mathrm{kg}^{-1}\right)$ treatment therefore is not safe for plant protection practices on vegetables, which are harvested frequently and for human consumption of eggplant fruits, unless suitable decontamination practices are adopted [35]. The MRL value of the methyl parathion on eggplant is not fixed, the data generated may help in examining the national MRL values. If the TMRC was calculated based on 3 day contaminated sample, the actual intake will be much less than that of 0 day contaminated samples. Even this was not enough to ensure safety, as the pesticide is far more toxic (lower $\left.\mathrm{LD}_{50}\right)$ to mammals than indoxacarb $\left(\mathrm{LD}_{50}\right.$ male rat $\left.3619 \mathrm{mg} \cdot \mathrm{kg}^{-1}\right)$ or thiacloprid $\left(\mathrm{LD}_{50}\right.$ male rat $\left.836 \mathrm{mg} \cdot \mathrm{kg}^{-1}\right)$ and affects cholinesterase activity irreversibly [36].

\subsection{Efficacy of Synthetic Insecticides}

Indoxacarb. The per cent reduction on the weight and number basis of eggplant fruits showed almost similar effectiveness of indoxacarb treatments on ESFB population in both first year and second year (Table 9). Statistical analysis of the data showed that considering critical difference (CD) $5 \%$, efficiency of double dose was not significantly different from that of the lower dose. The higher treatment rate i.e. $150 \mathrm{~g} \cdot \mathrm{ai} \cdot \mathrm{ha}^{-1}$ was marginally, but not statistically more effective and ESFB population could be controlled through out the experimental period even after 15 days from both the sprays. The data revealed better efficacy of indoxacarb against this insect even at lower dose and hence application of this insecticide at recommended dose could enhance the yield sig- 
(Solanum melongena L.) and Pesticide Residue Dissipation Pattern

Table 8. Dissipation rates and half life values of indoxacarb, thiacloprid and methyl parathion on eggplant fruits.

\begin{tabular}{|c|c|c|c|c|c|}
\hline Insecticide & Spray & $\begin{array}{c}\text { Treatment level } \\
\left(\mathrm{g} \cdot \mathrm{ai} \cdot \mathrm{ha}^{-1}\right)\end{array}$ & $\begin{array}{c}\text { Correlation coefficient } \\
(\mathrm{r})\end{array}$ & $\begin{array}{l}\text { Half life } \\
\text { (day) }\end{array}$ & Regression equation \\
\hline \multirow{4}{*}{ Indoxacarb } & \multirow{2}{*}{ First year } & 75 & -0.822 & 3.9 & $\mathrm{Y}=1.71-0.090 \mathrm{X}$ \\
\hline & & 150 & -0.842 & 3.0 & $\mathrm{Y}=2.53-0.133 \mathrm{X}$ \\
\hline & \multirow{2}{*}{ Second year } & 75 & -0.827 & 3.8 & $\mathrm{Y}=1.75-0.093 \mathrm{X}$ \\
\hline & & 150 & -0.847 & 2.9 & $\mathrm{Y}=2.56-0.134 \mathrm{X}$ \\
\hline \multirow{4}{*}{ Thiacloprid } & \multirow{2}{*}{ First year } & 30 & -0.986 & 11.1 & $\mathrm{Y}=3.07-0.117 \mathrm{X}$ \\
\hline & & 60 & -0.992 & 11.6 & $Y=5.00-0.199 X$ \\
\hline & \multirow{2}{*}{ Second year } & 30 & -0.985 & 11.1 & $\mathrm{Y}=3.08-0.118 \mathrm{X}$ \\
\hline & & 60 & -0.991 & 11.5 & $Y=5.01-0.198 X$ \\
\hline \multirow{4}{*}{ Methyl parathion } & \multirow{2}{*}{ First year } & 100 & -0.933 & 6.0 & $\mathrm{Y}=2.90-0.123 \mathrm{X}$ \\
\hline & & 200 & -0.959 & 7.4 & $\mathrm{Y}=3.41-0.140 \mathrm{X}$ \\
\hline & \multirow{2}{*}{ Second year } & 100 & -0.936 & 6.1 & $\mathrm{Y}=2.96-0.125 \mathrm{X}$ \\
\hline & & 200 & -0.959 & 7.3 & $\mathrm{Y}=3.47-0.143 \mathrm{X}$ \\
\hline
\end{tabular}

Table 9. Efficacy of synthetic and biopesticides against ESFB.

\begin{tabular}{|c|c|c|c|c|c|}
\hline \multirow{3}{*}{ Insecticide } & \multirow{3}{*}{ Treatment } & \multicolumn{4}{|c|}{ Percent fruit damage } \\
\hline & & \multicolumn{2}{|c|}{ First year } & \multicolumn{2}{|c|}{ Second year } \\
\hline & & Weight basis & Number basis & Weight basis & Number basis \\
\hline \multirow{3}{*}{$\begin{array}{l}\text { Indoxacarb } \\
\left(\mathrm{g} \cdot \mathrm{ai} \cdot \mathrm{ha}^{-1}\right)\end{array}$} & 150 & 8.53 & 16.27 & 7.20 & 19.47 \\
\hline & Control & 28.68 & 41.35 & 31.54 & 47.28 \\
\hline & CD@5\% & 3.45 & 8.22 & 5.81 & 11.43 \\
\hline \multirow{5}{*}{$\begin{array}{l}\text { Thiacloprid } \\
\left(\mathrm{g} \cdot \mathrm{ai}^{\circ} \cdot \mathrm{ha}^{-1}\right)\end{array}$} & 60 & 12.87 & 28.64 & 11.57 & 29.79 \\
\hline & 120 & 11.56 & 25.73 & 9.88 & 26.45 \\
\hline & 240 & 9.24 & 19.26 & 8.14 & 23.59 \\
\hline & Control & 17.38 & 37.74 & 15.78 & 35.28 \\
\hline & CD@5\% & 1.24 & 2.88 & 1.39 & 2.67 \\
\hline \multirow{3}{*}{$\begin{array}{l}\text { Methyl parathion } \\
\quad\left(\mathrm{g} \cdot \mathrm{ai} \cdot \mathrm{ha}^{-1}\right)\end{array}$} & 100 & 13.45 & 26.35 & 11.98 & 31.43 \\
\hline & 200 & 9.89 & 17.46 & 10.34 & 16.26 \\
\hline & CD@5\% & 5.43 & 11.24 & 4.37 & 16.88 \\
\hline \multirow{4}{*}{$\begin{array}{c}\text { BiolepTM } \\
\left(\mathrm{kg} \cdot \text { formulation } \cdot \mathrm{ha}^{-1}\right)\end{array}$} & 1.0 & 15.86 & 29.79 & 14.63 & 24.34 \\
\hline & 2.0 & 12.74 & 21.44 & 12.88 & 20.62 \\
\hline & Control & 22.82 & 34.68 & 24.89 & 36.73 \\
\hline & CD@5\% & 2.54 & 6.46 & 1.38 & 2.62 \\
\hline \multirow{4}{*}{$\begin{array}{c}\text { PUSA BtTM } \\
\left(\mathrm{kg} \cdot \text { formulation } \cdot \mathrm{ha}^{-1}\right)\end{array}$} & 1.0 & 16.34 & 22.59 & 13.54 & 23.21 \\
\hline & 2.0 & 12.94 & 18.82 & 11.68 & 19.56 \\
\hline & Control & 19.62 & 29.78 & 25.44 & 28.43 \\
\hline & CD@5\% & 5.98 & 6.77 & 4.86 & 9.18 \\
\hline \multirow{4}{*}{$\begin{array}{l}\text { NSKE } \\
\text { (Percent) }\end{array}$} & 5 & 19.65 & 23.93 & 18.23 & 24.34 \\
\hline & 10 & 16.43 & 18.42 & 12.88 & 20.61 \\
\hline & Control & 22.87 & 26.73 & 24.90 & 36.72 \\
\hline & CD@5\% & 4.87 & 7.62 & 8.84 & 6.43 \\
\hline \multirow{2}{*}{$\begin{array}{c}\text { Nimbo BasTM } \\
\left(\mathrm{mL} \cdot \text { formulation } \cdot \mathrm{ha}^{-1}\right)\end{array}$} & 100 & 17.65 & 21.23 & 18.24 & 22.34 \\
\hline & 200 & 14.33 & 16.64 & 15.68 & 18.64 \\
\hline
\end{tabular}

nificantly i.e. 239.4 quintal $\mathrm{ha}^{-1}$ as compared to 125.2 quintal $\cdot \mathrm{ha}^{-1}$ from untreated plots, without any adverse effect on the quality of eggplant fruits. Indoxacarb at the experimented doses $\left(75\right.$ and $150 \mathrm{~g} \cdot \mathrm{ai} \cdot \mathrm{ha}^{-1}$ ) was effective in managing ESFB and did not pose residue problem in fruits. A waiting period of $3 \mathrm{~d}$ for harvest of the fruits after insecticide application and processing factor (PF) could ensure desirable margin of safety (MOS) and hence no health risk situations are encountered from the use of this insecticide on eggplant crop.

Thiacloprid. The data on the per cent reduction on the weight and number basis of eggplant fruits showed almost similar action of thiacloprid treatments on ESFB population in both the years considering $\mathrm{CD}$ values, for 
both concentrations of application (Table 9). Statistical analysis showed that there was only marginal advantage in applying the higher dose, but fruit damage was statistically significant in control plots as compared to those collected from treated plots at all doses in both years. It is clear from observations that thiacloprid is not effective enough for controlling ESFB in eggplant crop, although it could reduce the Eggplant leaf hopper, Amrasca devastans infestation. Thiacloprid at the experimented doses (30 and $60 \mathrm{~g} \cdot a i \cdot \mathrm{ha}^{-1}$ ) was not effective in managing ESFB and was not safe for human consumption even after a waiting period of 3 days. A waiting period of $3 \mathrm{~d}$ for harvest of the fruits after insecticide application and PF could not ensure sufficient margin of safety (MOS). Health risk may be encountered from the use of this insecticide on eggplant crop. The study reiterates that new pesticides must be evaluated for safety, contrary to general belief that newer pesticides are safer to mammals and beneficial insects because they are effective at low dosages. No phytotoxicity was observed for $4 \times$ dose, i.e. $120 \mathrm{~g} \cdot \mathrm{ai}^{\mathrm{h}} \mathrm{ha}^{-1}$ of thiacloprid in field. The yield data for treated plots were only marginally better i.e. 134.5 from treated plots to 125.2 quintal $\cdot \mathrm{ha}^{-1}$ from untreated plots.

Methyl parathion. The data on the efficacy of methyl parathion at two treatment levels were evaluated based on the damaged fruit count by per cent weight and by per cent number. Although methyl parathion is not recommended in vegetables in India, farmers use this pesticide widely against ESFB. The data on the per cent reduction on the weight and number basis of eggplant fruits showed similar effect of methyl parathion treatments on ESFB population (Table 9). The statistical analysis showed that $200 \mathrm{~g} \cdot \mathrm{ai} \cdot \mathrm{ha}^{-1}$ was more effective and the ESFB population was controlled through out the experimental period. The higher dose was not statistically more effective than the lower dose $\left(100 \mathrm{~g} \cdot \mathrm{ai} \cdot \mathrm{ha}^{-1}\right)$. The data revealed the efficacy of methyl parathion against ESFB even at lower dose, but since the residue profile study showed that methyl parathion residues are persistent on eggplant fruits above MRL (Figure 3; Table 8), there is health risk beyond doubt and the insecticide cannot be included in good agricultural practice for growing this crop.

\subsection{Efficacy of Bio/Botanical Insecticides}

Biolep. The data on the per cent reduction on the weight and number basis of eggplant fruits showed similar effect of Biolep treatments on ESFB population (Table 9). Analysis of data showed that both the doses were not statistically effective in managing ESFB.

PUSA Bt. The potency of the formulation was 50000 I.U. $\mathrm{mg}^{-1}$ minimum on a surrogate insect Helicoverpa armigera. The statistical analysis of data on the per cent reduction on the weight and number basis of eggplant fruits showed PUSA Bt was significantly effective on ESFB population (Table 9). Both the doses were effective in controlling the pest and it was found that PUSA $\mathrm{Bt}$ gave better result in controlling the key pest when compared to Biolep. The higher treatment rate $(2 \mathrm{~kg}$ formulation $\cdot \mathrm{ha}^{-1}$ ) was slightly more effective when compared to $1 \mathrm{~kg}$ formulation $\cdot \mathrm{ha}^{-1}$ dose.

NSKE. The data on the per cent reduction on the weight and number basis of eggplant fruits showed that both doses of NSKE were significantly effective on ESFB (Table 9). The higher treatment rate gave better control than $5 \%$ dose.

Nimbo Bas. The data on the per cent reduction on the weight and number basis of eggplant fruits showed no significant effect for both the doses of Nimbo Bas on ESFB (Table 9).

\subsection{Correlation of Seven Treatments and Control}

In field, all seven treatments were not statistically significant $(\mathrm{CD}$ at $5 \% 12.93)$ from each other when compared to the yield from control $(28 \mathrm{~kg})$. It showed slightly higher yields for synthetic insecticides (mean weight 36 $38 \mathrm{~kg}$ ) as compared to biopesticides (mean weight 25 $31 \mathrm{~kg}$ ). Among synthetic insecticides, methyl parathion and thiacloprid were found to be of persistent nature and left toxic residue above maximum residue limit (MRL). Therefore taking second criteria of persistence along with the first criteria of yield, indoxacarb is the only treatment which can be applied after fruiting in eggplant crop. Once fruiting has begun, only bio-pesticides like Bt or NSKE should be recommended to avoid residue hazard and to manage ESFB. NSKE was found superior to Neem oil based Nimbo Bas against this pest. However, Nimbo Bas was found to be effective for some of the sucking pests. Similar yield recorded in control plots is due to contribution of cultural practices adopted for plant protection. This involved monitoring of holes on the tip of the branches, removal of the infected twig and burying them. Application of bio-insecticides (Biolep or PUSA Bt) or botanical insecticide (NSKE and Nimbo Bas) could improve the yield due to management of this and other pests like leaf hopper. Application of synthetic insecticides afforded maximum yield of 239 quintal $\cdot \mathrm{ha}^{-1}$ verses 125 quintal $\cdot \mathrm{ha}^{-1}$ realized from control plots subjected to only good agricultural practice of the region. From the results of this three-year research, an IPM package is being proposed for validation and refinement (Table 10).

\section{Conclusion}

This study involved the efficacy studies of three chemical and four bio-pesticides for the management of ESFB. Analytical methods were developed for indoxacarb, thia- 
(Solanum melongena L.) and Pesticide Residue Dissipation Pattern

Table 10. Proposed IPM schedule for eggplant cultivation.

\begin{tabular}{|c|c|c|c|}
\hline Stage of crop & Operation & Targeted Pests/Advantages & Remarks \\
\hline Before sowing & $\begin{array}{l}\text { FYM@ } 95 \mathrm{~kg} \mathrm{bed}^{-1}\left(5 \times 1 \mathrm{~m}^{2}\right)+0.5 \mathrm{~kg} \\
\text { neem cake }\end{array}$ & & Mandatory \\
\hline \multicolumn{4}{|c|}{ He } \\
\hline & Treatment with Captan ${ }^{\mathrm{TM}} @ 2 \mathrm{~g} \cdot \mathrm{L}^{-1}$ & Fungal diseases/root rot & Mandatory \\
\hline Nursery bed & Apply Chlorpyrifos to nursery beds & Soil insects & Mandatory \\
\hline \multicolumn{4}{|l|}{ Field } \\
\hline $15 \mathrm{~d}$ before transplanting & FYM@10 tons $\cdot h^{-1}$ in field & & Mandatory \\
\hline \multirow[t]{2}{*}{$1 \mathrm{~d}$ before transplanting } & $\begin{array}{l}\text { NPK; Spacing given as } 60 \times 75 \mathrm{~cm}^{2} \\
\left(\text { instead of } 60 \times 60 \mathrm{~cm}^{2} \text { ) }\right.\end{array}$ & Bacterial and fungal diseases & Optional \\
\hline & $\begin{array}{l}\mathrm{P} \text { and } \mathrm{K} @ 60 \mathrm{~kg} \cdot \mathrm{ha}^{-1} \mathrm{P}_{2} \mathrm{O}_{5} \text { and } \\
40 \mathrm{~kg} \cdot \mathrm{ha}^{-1} \mathrm{~K}_{2} \mathrm{O}\end{array}$ & & \\
\hline \multicolumn{4}{|l|}{ Transplanted crop } \\
\hline $7 \mathrm{~d}$ after transplanting & Half N@50 kg·ha ${ }^{-1}$ urea & Reduce sucking pests like jassids, whitefly etc. & Mandatory \\
\hline \multirow[t]{5}{*}{$35 \mathrm{~d}$ after transplanting } & Half N@50 kg·ha ${ }^{-1}$ urea & -do- & Mandatory \\
\hline & Manual weeding & Weeds are hosts of pests and diseases. & Mandatory \\
\hline & $\begin{array}{l}\text { Removal of infected shoots, Neem cake } \\
2.5 \mathrm{q} \cdot \mathrm{ha}^{-1}\end{array}$ & Shoot borer & Mandatory \\
\hline & Spray with methyl parathion & Jassids & Optional \\
\hline & Remove infected branches & Shoot borer & Mandatory \\
\hline $\begin{array}{l}45 \text { d after transplanting } \\
\text { (Flowering starts) } \\
\text { At fruit setting }\end{array}$ & Spray with thiacloprid@30·g·ai $\cdot \mathrm{ha}^{-1}$ & Jassids and sap sucking pests & Optional \\
\hline After first harvest & Spray indoxacarb@75 g·ai/ha & ESFB & Mandatory \\
\hline \multirow[t]{2}{*}{$60 \mathrm{~d}$ after transplanting } & NSKE (5\%) spray & ESFB & Mandatory \\
\hline & Pheromone traps (100 number $\cdot h^{-1}$ ) & ESFB & Mandatory \\
\hline \multirow[t]{2}{*}{$75 \mathrm{~d}$ after transplanting } & Remove infected fruits/phytosanitation & Reduce pest population & Mandatory \\
\hline & $\begin{array}{l}\text { BiolepTM, PUSA Bt, Neem oil sprays } \\
\text { (a) } 14 \mathrm{~d} \text { interval }\end{array}$ & Plant protection/plant resistance & Optional \\
\hline $120 \mathrm{~d}$ after transplanting & NSKE $(5 \%)$ & ESFB, Plant protection/plant resistance. & Mandatory \\
\hline
\end{tabular}

*FYM-Farm yard manure; NPK — Nitrogen, Phosphorus, Potassium; q-quintal.

cloprid and methyl parathion from eggplant and their dissipation pattern were evaluated. The half lives of these synthetic insecticides were around 3, 11, 6 days, respectively (Table 8). It was found that indoxacarb was effective against ESFB where as thiacloprid was not effective against this pest and left high residues on the fruits. Methyl parathion was found effective although it is not recommended against ESFB in eggplant in India, as it left toxic residue on the fruits. Methyl parathion and thiacloprid can be applied only before fruiting stage. Among the bio-pesticides PUSA Bt was found significantly effective than Biolep formulation. Also, NSKE was found significantly effective over Nimbo Bas formulation. There is a need for a new improved IPM package for the management of ESFB in India. The proposed IPM package needs to be refined and validated further.

\section{REFERENCES}

[1] A. S. Sidhu and A. S. Dhatt, "International Conference on Indigenous Vegetables and Legumes-Prospectus for Fighting Poverty, Hunger and Malnutrition: Current Status of Brinjal Research in India," ISHS Acta Horticulturae, Vol. 752, 2007, pp. 243-248.

[2] K. Matsubara, T. Kaneyuki, T. Miyake and M. Mori, "Antiangiogenic Activity of Nasunin, an Antioxidant Anthocyanin in Eggplant Peels," Journal of Agricultural and Food Chemistry, Vol. 53, No. 16, 2005, pp. 62726275. doi:10.1021/jf050796r

[3] G. Oboh, M. M. Ekperigin and M. I. Kazeem, "Nutritional and Hemolytic Properties of Eggplant (Solanum macrocarpon) Leaves," Journal of Food Composition and Analysis, Vol. 18, No. 2-3, 2005, pp. 153-160. doi:10.1016/j.jfca.2003.12.013

[4] M. S. Rahman, M. Z. Alam, M. Haq, N. Sultana and K. S. Islam, "Effect of Some Integrated Pest Management (IPM) Packages against Brinjal Shoot and Fruit Borer," Journal of Biological Sciences, Vol. 2, No. 7, 2002, pp. 489-491.

[5] M. Schuld and R. Schmuck, "Effects of Thiacloprid, a New Chloronicotinyl Insecticide on the Egg Parasitoid Trichogramma cacaoeciae," Ecotoxicology, Vol. 9, No. 3, 2000, pp. 197-205. doi:10.1023/A:1008994705074

[6] P. J. Charmillot, D. Pasquier, C. Grela, M. Genini, R. Olivier, C. Ioriatti and A. Butturini, "Resistance of Carprocapsid Cydia pomonella to Insecticides," Arboricul- 
ture et Horticulture, Vol. 35, 2003, pp. 363-368.

[7] Z. Puciennik, R. W. Olszak and U. Tworkowska, "Assessment of the Efficacy of Selected Insecticides in Controlling the Plum Fruit Moth (Laspeyresia funebrana)," Zeszyty Naukowe Instytutu Sadownictwai Kwiaciarstwaw Skierniewicach, Vol. 11, 2003, pp. 125-128.

[8] M. D. Doerr, J. F. Brunner and L. E. Schrader, "Integrated Pest Management Approach for a New Pest, $L a-$ canobia subjuncta (Lepidoptera: Noctuidae) in Washington Apple Orchards," Pest Management Science, Vol. 60, No. 10, 2004, pp. 1025-1034. doi:10.1002/ps.912

[9] B. H. Labanowska and Z. Partyka, "Monitoring and Control of currant Clearwing Moth (Synanthedon tipuliformis) on Black Currant," Journal of Plant Protection Research, Vol. 44, 2004, pp. 929-932.

[10] B. H. Labanowska, C. Linder and J. V. Cross, "Pest Control in Blackcurrant in Poland Using the New Neonicotinoid, Thiacloprid as Calypso 480 SC," Bulletin of International Organization for Biological and Integrated Control of Noxious Animals and Plants, Vol. 27, 2004, pp. 101-106.

[11] J. Stará and F. Kocourek, "Insecticidal Resistance and Cross-Resistance in Populations of Cydia pomonella (Lepidoptera: Tortricidae) in Central Europe," Journal of Economic Entomology, Vol. 100, No. 5, 2007, pp. 15871595. doi:10.1603/0022-0493(2007)100[1587:IRACIP]2.0.CO; $\underline{2}$

[12] M. Tomizawa and J. E. Casida, "Neonicotinoid Insecticide Toxicology: Mechanisms of Selective Action," Annual Review of Pharmacology and Toxicology, Vol. 45, 2004, pp. 247-268.

[13] K. D. Wing, M. Sacher, Y. Kagaya, Y. Tsurubuchi, L. Mulderig, M. Connair and M. Schnee, "Bioactivation and Mode of Action of the Oxadiazine Indoxacarb in Insects," Crop Protection, Vol. 19, No. 8-10, 2000, pp. 537-545. doi:10.1016/S0261-2194(00)00070-3

[14] X. P. Hu, "Evaluation of Efficacy and Non-Repellency of Indoxacarb and Fipronil-Treated Soil at Various Concentrations and Thicknesses against Two Subterranean Termites (Isoptera: Rhinotermitidae)," Journal of Economic Entomology, Vol. 98, No. 2, 2005, pp. 509-517. doi:10.1603/0022-0493-98.2.509

[15] F. R. Musser and A. M. Shelton, "Bt Sweet Corn and Selective Insecticides: Impacts on Pests and Predators," Journal of Economic Entomology, Vol. 96, 2003, pp. 7180. doi:10.1603/0022-0493-96.1.71

[16] J. Z. Zhao, Y. X. Li, H. L. Collins, L. Gusukuma-Minuto, R. F. L. Mau, G. D. Thompson and A. M. Shelton, "Monitoring and Characterization of Diamondback Moth (Lepidoptera: Plutellidae) Resistance to Spinosad," Journal of Economic Entomology, Vol. 95, No. 2, 2002, pp. 430436. doi:10.1603/0022-0493-95.2.430

[17] C. L. Barr, "Fire Ant Mound and Foraging Suppression by Indoxacarb Bait," Journal of Agricultural and Urban Entomology, Vol. 20, No. 3, 2003, pp. 143-150.

[18] A. G. Appel, "Laboratory and Field Performance of an Indoxacarb Bait against German Cockroaches (Dictyop- tera: Blattellidae)," Journal of Economic Entomology, Vol. 96, No. 3, 2003, pp. 863-870. doi:10.1603/0022-0493-96.3.863

[19] S. F. McCann, G. D. Annis, R. Shapiro, D. W.Piotrowski, G. P. Lahm, J. K. Long, K. C. Lee, M. M. Hughes, B. J. Myers, S. M. Griswold, B. M. Reeves, R. W. March, P. L. Sharpe, P. Lowder, W. E. Barnette and K. D. Wing, "The Discovery of Indoxacarb: Oxadiazines as a New Class of Pyrazoline-Type Insecticides," Pest Management Science, Vol. 57, No. 2, 2001, pp. 153-164.

doi:10.1002/1526-4998(200102)57:2<153::AID-PS288>3 $\underline{.0 . \mathrm{CO} ; 2-\mathrm{O}}$

[20] C. Kao, C. Hung and C. Sun, "Parathion and Methyl Parathion Resistance in Diamondback Moth (Lepidoptera: Plutellidae) Larvae," Journal of Economic Entomology, Vol. 82, No. 5, 1989, pp. 1298-1304.

[21] T. V. Prasad, "Development of Water Dispersible Powder (WDP) Formulation of Bacillus thuringiensis var. kurstaki and Its Effect on Detoxification Enzymes of Helicoverpa armigera Hubner," Ph.D. Thesis, Indian Agricultural Research Institute, New Delhi, 2003.

[22] J. Saimandir, "Evaluation of Pesticide Residues on Eggplant, Solanum melongena L. Subjected to Plant Protection Measures for Control of Shoot and Fruit Borer, Leucinodes orbonalis Guen.," Ph.D. Thesis, Indian Agricultural Research Institute, New Delhi, 2005.

[23] W. M. Hoskins, "Mathematical Treatment of LOSS of Pesticide Residues," Food and Agriculture Organization Plant Protection Bulletin, Vol. 9, 1961, pp. 163-168.

[24] M. Gopal and I. Mukherjee, "MRL of Fenvalerate, HCH and Endosulfan on Chickpea," Annals of Plant Protection Sciences, Vol. 3, 1995, pp. 105-109.

[25] J. Saimandir and M. Gopal, "Analysis of Indoxacarb Applied for Managing Shoot and Fruit Borer, Leucinodes orbonalis G. of Eggplant (Solanum melongena L.) and Its Decontamination by Chemicals," Journal of Environmental Science and Health, Part B. Pesticides, Food Contaminants, and Agricultural Wastes, Vol. 44, 2009, pp. 292301.

[26] P. Subbian, K. Annadurai and S. P. Palaniappan, "Agriculture, Facts and Figures," Kalyani Publishers Ltd, New Delhi, 2000.

[27] S. Sinha and M. Gopal, "Evaluating the Safety of BetaCyfluthrin Insecticide for Usage in Eggplant (Solanum melongena L.) Crop," Bulletin of Environmental Contamination and Toxicology, Vol. 68, No. 3, 2002, pp. 400-405. doi:10.1007/s001280268

[28] C. D. S. Tomlin, "The Pesticide Manual, 7th Edition, A World Compendium," British Crop Protection Council, Hampshire, 2006.

[29] Codex Alimentarius Commission, 2008. http://www.codexalimentarius.net/mrls/servlet/pesticides/ jsp/pest_q-e.j\&p

[30] W. M. Hoskins, "Mathematical Treatment of Loss of Pesticide Residues," Food and Agriculture Organization Plant Protection Bulletin, Vol. 9, 1961, pp. 163-168.

[31] Food and Agriculture Organization, 2008. 
http://www.fao.org/ag/AGP/AGPP/Pesticid/JMPR/Downl oad/2006_rep/Thiacloprid.pdf

[32] WHO (World Health Organization), "Guidelines for Predicting Dietary Intake of Pesticide Residues," Program of Food Safety and Food Aid, Geneva, Switzerland, 1997.

[33] S. Jayakrishnan, M. Gopal and S. Walia, "Risk Assessment of Thiacloprid and Its Chemical Decontamination from Eggplant, Solanum melongena L.," Pest Management Science, Vol. 65, No. 2, 2009. pp. 210-215. doi:10.1002/ps.1670

[34] Food and Agriculture Organization/World Health Organization, "Acceptable Daily Intakes, Acute Reference Doses, Short-Term and Long-Term Dietary Intakes, Rec- ommended Maximum Residue Limits and Supervised Trials Median Residue Values," Geneva, Switzerland, 2005.

[35] J. Saimandir, A. K. Dikshit, J. P. Singh and D. C. Pachauri, "Dissipation of Lambda-Cyhalothrin on Tomato (Lycopersicon esculentum Mill.) and Removal of Its Residues by Different Washing Processes and Steaming," Bulletin of Environmental Contamination and Toxicology, Vol. 75, No. 2, 2005. pp. 324-328. doi:10.1007/s00128-005-0756-2

[36] N. K. Roy, "Chemistry of Pesticide," 1st Edition, Cbs Publishers \& Distributors, New Delhi, India, 2002. 